\title{
MARKETING RESEARCH IN THE FUNCTION OF BUSINESS EFFICIENCY
}

\author{
Nedeljko Prdić1 ${ }^{1}$ Boris Kuzman², Jelena Damjanović3 \\ *Corresponding author E-mail: jelenaschoolofbusiness@gmail.com
}

\begin{abstract}
A R T I C LE IN F O
A B S T R A C T

Review Article

Received: 30 June2019

The aim of this work paper is to suggest efficient model of

Accepted: 16 October 2019 business efficiency in agro industrial products commerce, by integration of marketing mix instruments - product doi:10.5937/ekoPolj1904039P

UDC 339.138:658 and price. Marketing research provides solid bases for foundation of good and efficient management moment, as an assumption of good market position. Based on determined goals and research objects, using qualitative

Keywords:

marketing research, agro methods of marketing research, the goal is the establishment of functional model of business efficiency. Another aim is industrial products, commerce, business efficiency

JEL: M21, M210, Q13 to establish efficient communication model for interested parts, on relation service provider (enterprise), retailer, buyer and consumer in agro industrial products commerce within special market institutions (wholesale markets).
\end{abstract}

(C) 2019 EA. All rights reserved.

\section{Introduction}

Having in mind the significance of specialized market institutions in agro industrial is complex, during determination of work papers' goals, the accent is put on strategy of using these institutions (wholesale markets) as place of meeting supply and demand of agro industrial products, emphasizing that such institutions are obsolete. The intention is to point out the development of wholesale markets in the world, since they enable efficient meeting of supply and demand of goods, and to present the possibility for creation of such market conditions on domestic market too.

The object of analysis in the sense of commerce is related to agroindustrial products commerce, primarily fruits and vegetables as most important products in commercial sense, observed from the aspect of sold quantities and also mutual dependence between employer (enterprise) - service buyer (retailer), final consumer (buyer or consumer). Having in mind

1 NedeljkoPrdić, Ph.D., Assistant Professor., JKP Tržnica, 4 Žike Popovića Street, SRB21000 Novi Sad, Serbia, Phone: +381 63500 818, E-mail: ekonomistdoo@sbb.rs, ORCID ID https://orcid.org/0000-0003-3199-1188

2 Boris Kuzman, Ph.D., Associate Professor, Institute of Agricultural Economics, 15 Volgina Street, SRB-11060 Belgrade, Serbia, Phone: +381 63590 129, E-mail: kuzmanboris@ yahoo.com, ORCID ID https://orcid.org/0000-0002-8661-2993

3 Jelena Damnjanović Ph.D, School of business, Novi Sad, E-mail: jelenaschoolofbusiness@, gmail.com, ORCID ID https://orcid.org/0000-0001-8692-3751

http://ea.bg.ac.rs 
the importance of wholesale markets in selling system of product, the accent is on elements of business efficiency strategy, and the influence of individual and integrated marketing mix instruments on business efficiency. The model which represents the significance of agroindustrial products commerce and its contribution to business effects, puts the marketing mix instruments in frameworks that enable efficient usage of these instruments for securing competitive market position of seller and service provider (wholesale markets) for achievement of business goals. On the other side, this model enables the satisfaction of market needs, in the function of satisfying needs of buyers and consumers. In domestic literature, there are many works that theoretically and practically deal with agro industry problems. However, there is a lack of works that strategically point out the significance of wholesale markets for increase of commerce and business efficiency of domestic enterprises.

\section{Methods - goals and assumptions of research}

The assumptions of research originate from set aims based on defined research problem. These assumptions are starting points for relevant research conduct that would lead to acceptable recommendations or conclusions. The first set hypothesis has aim to form such model of acceptable prices, renting of selling places, business offices and other objects that serve for achievement of enterprise income and interest of sellers.

H1: The more acceptable the price of selling places, the greater effects of income increase of enterprise and sellers of products.

The other hypothesis has an aim to establish efficient model of marketing communications with business space renters (sellers), service provider (enterprise) and buyers and consumers as final users.

H2: The greater extent of communication integration between service provider (enterprise), service user (sellers) and consumers, the greater is the efficiency of business.

The intention is to use theoretical methods of observation and marketing research methods and prove set hypotheses and achieves concise theoretical consideration of the problem, with adequate conclusions that will explain the essence of business relation employer renter, buyer - consumer, in order to increase the sales and improve business efficiency. The aim of this work paper is to establish economic efficiency model, and model communication efficiency, which practice implementation in the sense of integration and direction to buyers, will create credible model of business efficiency.

For proving the hypothesis and to gather data of commerce state in agro industry, the data gathering is performed on retail markets and wholesale markets of agro industrial products, in order to prove set hypothesis, for increase of business efficiency using marketing mix instruments. Performed researches are based on usage of special methods of cognition and marketing research methods that are adjusted to research problem needs. Special methods used in the work are methods of analysis and synthesis, method of logical deduction and quantitative methods. In marketing research, the comparative method is used. It is composed from two methods: historic method and examination method. Historic method is used for gathering 
data and information from secondary sources, professional and other public, and the author's research based on theoretical and practical experience with special market institutions (fairs, wholesale markets, bazaars), while examination method i.e. terrain investigation is used to gather qualitative data and information. The intention is to prove set hypotheses and to achieve concise theoretical consideration of problem and adequate conclusions that will explain the essence of business relation between service provider, seller and final user, for improvement of selling and communications in order to increase business results.

\section{Basic elements of business efficiency strategy}

\section{The importance of agroindustrial product commerce}

The importance of agro industrial products within total products market takes special place, due to specificity of production process in agriculture. The importance of commerce of agro industrial products is realised by distribution and sale of products within system of wholesale markets. For the relevance of analysis of agro industrial products, there is a presentation of the enterprise that rents space for commerce of these goods.

Table 1. Revenue generated from renting space on retail market

\begin{tabular}{|l|c|c|c|c|c|c|}
\hline $\begin{array}{c}\text { Month / } \\
\text { year }\end{array}$ & $\mathbf{2 0 1 0}$ & $\mathbf{2 0 1 1}$ & $\mathbf{2 0 1 2}$ & $\mathbf{2 0 1 3}$ & $\mathbf{2 0 1 4}$ & $\mathbf{2 0 1 5}$ \\
\hline $\mathbf{1 - 4}$ & 17.659 .071 & 18.546 .764 & 19.197 .896 & 21.652 .221 & 20.514 .728 & 20.832 .655 \\
\hline $\mathbf{5 - 8}$ & 24.593 .225 & 24.852 .750 & 26.048 .494 & 29.231 .468 & 25.833 .324 & 25.591 .548 \\
\hline $\mathbf{9 - 1 2}$ & 19.980 .434 & 20.167 .205 & 22.164 .321 & 22.032 .445 & 20.734 .782 & 20.648 .538 \\
\hline Revenue & 62.232 .730 & 63.566 .719 & 67.410 .711 & 72.916 .134 & 67.082 .834 & 67.072 .741 \\
\hline
\end{tabular}

Source: "Periodic Income Statement for the period 2010-2015. year “, TKPTržnica, Novi Sad

Based on data from previous table we may conclude that income generation of actual enterprise (service provider) is on maximum in period from May to August. In this period, possibilities for commerce are increased and other circumstances are better. It is necessary to mention that result of income increase of five million dinars during 2013 is the result of renting price increase of 3\%. Based on practical knowledge of author of this work paper in sense of intuition and objective observation of market conditions and competition, it is necessary to harmonise marketing instruments, product (service), acceptable prices of services (products), and different instruments of marketing communications.

Evaluation of markets is performed with the aim to gather information that may be base for creating the model of markets categorisation. Key criteria are:

- Place where market is settled, regarding its attractiveness for greater number of sellers and buyers (central market or central markets, if there is more than one),

- Size of infrastructure facilities(open or covered, finery amortisation rate, number of refrigerated cabinet, number of units, sanitary conditions, drinking fountains, parking spaces and so on)

- $\quad$ The number of potential users (Duvnjak, 2013). 
Table 2. The most efficient forms of business income generating for service provider (enterprise)

\begin{tabular}{|l|}
\hline BUILDING OF MODERN TRADE CENTRES - OPEN AND CLOSED TRADE PLACES FOR \\
FRUIT AND VEGETABLES, AND OTHER AGROIDUSTRIALPRODUCTS - WHOLESALE \\
MARKETS - WHOLESALES OF AGRO INDUSTRIAL PRODUCTS \\
\hline Renting business and other areas by acceptable prices \\
\hline Provision of adequate closed and opened areas for commerce \\
\hline Efficient organisation of external and internal traffic \\
\hline Building system for product preservation for longer period of time - freezing - cooling \\
\hline Business strategy based on long term mutual interests \\
\hline
\end{tabular}

Source: Research results for requirements of this work

Economic efficiency of revenue obtaining depends of readiness of service provider to create such business conditions that may enable wholesales to sell their products (fruit and vegetables) by acceptable price with achievement of maximum income. Commerce of agro industrial products on wholesale markets, demand additional conditions that service provider has to fulfil, and that will affect the revenues of seller and satisfaction of consumer in retail sales and practical value for consumer as final user (Table 2).Modern way of trade has brought changes in the sense of organisation of wholesale markets as commerce areas, internal and external traffic as conditions for creation of greater trade centres for these products. Great competition in forms of supermarkets, big commodities centres in which sale point is possible to find fruit and vegetables and imported products, may greatly influence on domestic production survival and development of this trade form. The importance of commerce on such sale places dates from ancient times and represents the first form of commerce on public places. The market are all relations of supply and demand made for goods and services exchange, in defined time and on defined place. (Vlahović, 2013). Due to lack of financial assets, agriculture producers are often forced to sell grains strait after harvest, when the price is usually the lowest. (Zakić et al., 2014). Because of that, producers must take care about financial risk and financial assets (Kovacova \& Kliestik, 2017; Valaskova, 2018; Kliestik et al., 2018)

Integration of product offers - through the development of agricultural clusters, strengthening farmers associations, the promotion of agricultural cooperatives; only by joining farmers have the ability to compensate for what each of them lacks (finance, procurement of cheaper inputs, modern machinery and technology), with a significant increase in their bargaining power - both in relation to the state, and in relation to the food industry, trade, exporters. (Paraušić et al., 2007). Wholesale market is special market institution in trading of wide spectre, primarily perishable agricultural food products and other similar products. Foreign experience in functioning has shown that the most important goods in wholesale market trading are: fruit and vegetable, meat (fresh), fish and flowers. Yet, the most often products on wholesale markets are fruit and vegetables. (Lovreta, 2008).

In market-developed countries, wholesale markets survive and develop in the context of changing market circumstances, as an essential link between production and consumption in the trade of agricultural products (Kuzman et al. 2018). With the development of trade, urban 
infrastructure, competitive market, wholesale market location, and development strategies, they focus on the main roads on the outskirts of cities, for more efficient transportation, traffic congestion, pollution and noise, but also create conditions for competitive advantage over other distribution centres. (Kuzman et al. 2017). The conservation of food by freezing is performed by short and quick processing procedure, and significantly extends food durability and preserving the high quality of the food. (Vlahović et al., 2014).

All that gives the character to the wholesale market as intermediate place in trading. They are, beside producer, on the beginning of distribution chain of product placement. Wholesale market is primary agent in marketing channels of perishable goods that require special condition of storage and preservation. At the same time, it means that wholesale market as agent takes some functions in marketing channels, that are expensive to the others (since wholesale markets perform them at one place by economies of scale), or other intermediaries do not need to perform them, since they have opportunity to use wholesale markets (Lovreta, 2008). Agroindustrial products, primarily fruit and vegetables, may be incentives for agriculture sector development and one of contributors to better health of people, having in mind quality, freshness and controlled origins of products and standards that may contribute to development of more developed and specific industrial branches.

\section{Marketing research based on marketing mix instrument concept}

\section{Research based on concept of product - service}

In research for the needs of this work, the accent is on services provided by enterprises that rent business and other areas. It is their primary business and greatly contributes to their revenues. Incomes gathered by service selling make strong market position of enterprise - service provider, and also have certain influence on product sellers that use these spaces. The third, and the most important factor are buyers and consumers as product users, since their attitudes and purchases determine market position of seller and service provider. The quality is comparison the product or service to competitor's products and services, and based on familiar methods of quality checking, optimality of value and usefulness and other fact that may be useful for quality control of products and services. Quality of a product or service contribute to acceptable price that user is willing to pay for satisfaction of his or her needs. (Prdić, 2016).Safeness and quality of provided services, with all following elements, give basic conditions for selling products of high quality. The result is consumers' needs satisfaction. A consumer may buy quality product from famous and safe seller, on specific place. Product (or service) is a starting point of business efficiency model, based on marketing research that is necessary for service provider and trader of these goods.

\section{Research based on price concept}

The concept of prices as marketing instruments primarily arises because of synergy of all marketing instruments and other internal and external factors that may influence 
the price as basic marketing mechanism in conversion of products (merchandise) in money. The essence of the research based on price concept originates from the fact that enterprise as market subject generates financial means planned on goals and mission of market business. Low prices enable preservation of strategic marketing position and predictable number of buyers and consumers on the market. (Prdić, 2016). Prices are one of the most important marketing mix instruments. Price presents the amount of money needed for purchase of product or service that would satisfy needs of service users and consumers, or consumers or buyers of products. When speaking about price as an element of quality products, it is necessary to mention that price level depends on product's quality and from determination of the company to keep its buyers by lower prices and to attract new buyers and consumers in order to generate higher incomes and better market position. The prices are key marketing instrument that influence product and service sales, market position and clearly defined strategy for marketing mix instrument, in order to achieve effects that contribute to efficient business. Meeting interests of service consumers and final satisfaction of buyers and consumers based on the perception and attitudes are basic roles of prices as marketing instruments, according to marketing researches. The price is one of the key marketing mechanisms that one may use to achieve marketing goals. (Cotler et al., 2008). Based on researches performed on Retail market JKP Tržnica, the most important instruments for business success of sellers are:
- $\quad$ Price for renting $45 \%$
- Location of business place $\quad 25 \%$
- Permanent buyers 20\%
- $\quad$ Traffic infrastructure $\quad 8 \%$
- Other $2 \%$

When it comes to tenants' views on the amount of rent they pay and how much it affects business efficiency, the answers are as follows:

- Yes - it affects it but it is not the most important factor $38 \%$

- Yes - the lease price is a measure of our success $30 \%$

- No - the most important is the customer purchasing power $25 \%$

- Other $7 \%$.

The importance of prices as marketing instrument is observed from the position of enterprise that sells services. Prices are also significant as a basic element of agroindustrial products sales. Marketing mix instruments are directly connected by prices as instrument that influences on revenues of the enterprise and on good communication with permanent and potential users of services and satisfaction of important interests of buyers and consumers. Given that the price of the business space has a dominant role in pricing, as well as the possibility of safe sales to permanent customers, we conclude that the price is 
the dominant factor for business efficiency, that is, the hypothesis of the H1 research on the significance of the prices for business efficiency has been confirmed.

\section{Integration of sales and prices}

A good communication based on combination of high quality product and equivalent price, the efficiency in achievement of set economic and communication goals is realised. The final effect is improved business efficiency. When consumers buy a product, they exchange something valuable (price) for some other value (benefits of having or using product). The successful price determination oriented to buyers includes realization of value that consumers give to benefits of the products and determination of price suitable to such value. (Cotler et al., 2008). The most efficient instrument of marketing communication for attracting sellers to rent business places and selling points are:

- Opportunities for sellers income achievement

- Opportunities for recognition of location and product by buyers

- $\quad$ Strong marketing support of local printed and electronic media

- Efficiency in giving information to buyers and final consumers

- Marketing strategy of company based on the model of mutual interests of the company, seller (trader), buyers and consumers.

Selling agreement is the result of all activities and communication messages with the purpose to sell product or service, from the moment of first contact to the personal contact with seller and direct insight in products quality by the buyer and consumer that enjoys in high quality, acceptable, valuable and usable products.

\section{Integration of sales and word-of-mouth}

The most efficient selling instrument in the sense of assets invested for achievement of company's goals is service or product selling by word-of-mouth as the most direct way of communication, in the function of product or service sale on the market. The selling of agro industrial product is the most important segment of market positioning of the enterprise and the most significant indicator of business success. Personal selling directly influences on sales of the company. (Milisavljević, 2003).

The sales of products as marketing instrument, integrated with word-of-mouth in the sense of sales on selling point, is the approach in which seller and buyer determine mutual interest, based on certain quality and low prices, and also good communication that results with satisfaction of consumer as final market user.

\section{Optimal level of price and efficiency estimation}

The price level represents the market supply, and based on that we may measure and quantify the effect on sales and total business result. Price competitiveness makes relevant business strategy of "low prices" the significant factor of market advantage. If 
prices are low, it is a serious competitive advantage in the sense of more sold products, and with loyal buyers contributes to positive business effects. It would not be objectively to think that measurement of product or service quality is easy to perform. It is especially hard to objectively observe quantitative and qualitative attributes that represents the product and influence its price. Measuring the success is realized by quality, structure and usefulness of the product, and by price, that represents the reflection of invested assets for obtained product.

Table 3. Economic efficiency model

\begin{tabular}{|l|l|l|l|}
\hline \multicolumn{4}{|c|}{ ECONOMIC EFFICIENCY MODEL } \\
\hline $\begin{array}{l}\text { Interest of the enterprise } \\
\text { (service provider) }\end{array}$ & $\begin{array}{l}\text { Interest of seller } \\
\text { (trader of products) }\end{array}$ & $\begin{array}{l}\text { Interest of buyer } \\
\text { (trader of products) }\end{array}$ & $\begin{array}{l}\text { Interest of consumer } \\
\text { (final user) }\end{array}$ \\
\hline Effects on sales & Price of selling area & Acceptable price & Price and quality \\
\hline $\begin{array}{l}\text { Market } \\
\text { positioning }\end{array}$ & High quality product & High quality product & Variety of supply \\
\hline Strategic planning & Number of buyers & Repeated purchases & Location \\
\hline $\begin{array}{l}\text { Investments and } \\
\text { maintenance }\end{array}$ & Quantity of sales & Sales channels & Reliable seller \\
\hline
\end{tabular}

Source: Research results for requirements of this work

When speaking about hypothesis that acceptable price enables income increase for the company, we may certainly argue that income increase for service provider (enterprise) contributes to strategic partnership between space renter (commodity trader) with service provider, and with higher number of retail traders, in final instance enable maximum of usage of business and other areas and income increase for the company.A solid bases and recommendations, with confirmation of research hypotheses about increase incoms of provider and user of services and costumers satisfaction,provide suggested model of economic efficiency, based on marketing researches about attitudes, perception and interests of consumers.

\section{Research based on the concept of distribution channel (sales)}

Distribution of agricultural products must be adapted to a number of changes in the market environment. The importance of the market for agricultural products as part of the overall market takes a special place due to the specific nature of the production process in agriculture. When it comes to research for the purposes of this work, the form of wholesale trade in agro-industrial products is represented by quantum markets and wholesale markets, and from the aspect of distribution channels as a marketing instrument, it will be seen as an integrated mix of marketing instruments. It should be noted that the law of supply and demand has a very sensitive function when it comes to agricultural products (Prdić, 2016). The economic interest of the company that carries out business and other premises, as a segment in the distribution of agro-industrial products, is significant from the aspect of maximum utilization of the available space. 


\section{Research based on the concept of integrated communication}

A new approach to strategic management (enterprise) and consumer relationships implies the implementation of adopted generic and auxiliary strategies to keep the company in the market "game". The fact is that an increasing number of marketers in the marketplace are aware that the attitude towards consumers is very important, of strategic importance, and that it needs to be approached with great seriousness. Today there are really few retailers who do not emphasize the importance of the buyer in an effort to sell him a better product. The significance of customer orientation in markets is intensified through the concept of long-lasting cooperation in the form of loyalty and partnership with consumers (Prdić, 2014). When it comes to communication processes contained in the assumption of research, the intention is dual, theoretical, contained in elements of direct communication in the model of business efficiency, but also practical that shows the integrity, complexity, diversity and connection of the communication process among the important stakeholders contained in the elements of the business model efficiency. The effectiveness of a promotional message is achieved through the integrated approach of various marketing communication tools that make up one co-consistent and unique message to the targeted and other public. (Prdić, 2016).The intention is to work out, in fact, explain the essence of marketing communication in trade in agro-industrial products, in special or specialized market institutions such as wholesale markets, based on the adopted strategy of competitive advantage in relation to other segments of trade in these products, based on the principles and principles of marketing research and marketing communications.

\section{Integration of sales promotion - personal sales and word-of-mouth}

Sales promotion represents a systematic approach to the market based on the planned goals based on the interests of customers and consumers, after conducting research on market needs. Sales promotion is a very effective means of communication based on direct communication with relatively small assets. This type of promotion, combined with personal sales, enables the company more efficiency when it comes to sales and communication in relation to other mass communication tools. The sale is the most important instrument for the realization of the planned goals of travel marketing instruments and represents the satisfaction of the consumer or the customer for the acquired use value. It is not a rare case that terms of sale and negotiation are treated as synonyms. There is, however, the view that, although similar or even inseparable, sales and negotiation make various aspects of the sales task. (Pickton et al., 2001).Personal sales is one of the basic forms of marketing communication. At the same time, it is the only communication tool that is based on interpersonal communication. (Ognjanov, 2009). Personal sales are defined in the literature as face-to-face interaction with one or more potential customers in order to present the offer, to provide answers to questions and to obtain an order. (Kotler, 2003).Kindness to the client and efficient service can help keep clients as they build customer satisfaction and their commitment. It is estimated that client retention costs account for one fifth of the costs of acquiring a new client. 
(Smith, 2002).Word-of-mouth is an instrument in the function of personal sales and sales promotion when it comes to researching this work, in the form of achieving good communication and its integration for the purpose of selling products and generating revenue to the enterprise and satisfaction of consumers when its interest is satisfied through the use of products as end users. The most important instruments that may contribute to purchase increase on Retail market, according to research performed on sample of 500 buyers in the same period, are:

- Acceptable price $43 \%$

- $\quad$ Fresh and high quality product $28 \%$

- Seller's location $15 \%$

- High communication level with product sellers $14 \%$

In research for this work paper, one of the most important goals is purchase of products from sellers (traders) on wholesaler forms of commerce, since that selling (personal sale, word-of-mouth) is the most important segment of seller - buyer relation. Successful communication (personal sale and word-of-mouth), contribute to increase of income of buyers, that may buy products by acceptable prices on chosen market segment (wholesale markets), and consumers have interest to buy products of high quality by acceptable prices and distribution channels, that enable availability in the sense of nearness of product supply.

\section{Determination of optimal communication instrument}

Communication instruments should be harmonised, integrated and supported by several different instruments to create unique message that may contribute to efficient communication and increase of economic effects. In order to understand the difference between different instruments of communication, the influence on purchase process has to be measured primarily. In research of integration of communication instruments for this work, their efficiency is valued on the bases of mutual dependence, between instruments of selling, direct selling and word-of-mouth on purchase process. It is about the buyer's reaction to agro industrial products supply (fruit and vegetables) and buyer's decision to purchase products from certain seller.

The role of direct selling in communication mix is influenced by the phase of buying and selling process. In particular, phases of buying and selling process, consumers differently value certain forms of enterprise communications. The buying and selling process itself, as a line of activities where buyer and seller are involved, for the needs of direct selling analysis, may be divided to phase before purchase, purchase and usage. (Vračar, 2007). Purchase process is the description of demand behaviour, analysis that marks the path that potential buyer has chosen before the purchase (needs recognition, identifying alternative products and provider's estimation and decision about purchase). (Prdić, 2018). 
Table 4. Model of efficiency of communication

MODEL OF EFFICIENCY OF COMIMUNICATION

\begin{tabular}{|l|l|l|l|}
\hline $\begin{array}{l}\text { Enterprise } \\
\text { (service provider) }\end{array}$ & Seller & Buyer & Consumer \\
\hline $\begin{array}{l}\text { Tenant } \\
\text { (service user) }\end{array}$ & Buyers & Consumer centres & Frequency of sales \\
\hline Distribution channels & Consumer centres & Consumer interest & Buyers attitudes \\
\hline Buyers and consumers & Buying products & Product interest & $\begin{array}{l}\text { Perception of } \\
\text { consumers }\end{array}$ \\
\hline
\end{tabular}

Source: Research results for requirements of this work

When speaking about researches of communication efficiency, we need to mention that it is necessary to implement all of the elements of communication model, so that effect of a good communication would influence on business efficiency of the company, sellers and buyers. Integration of communication instruments achieves synergy effect in sense of realisation of mutual interests of companies, sellers, buyers and consumers, and confirms the research hypothesis that efficient marketing communication, contributes to better business results. About the communication instrument that are objects of research in this work, it is needed to stress that sales promotion, direct selling and word-of-mouth fall into most economical instruments of communication and their integration and implementation of communication model, contributes to economic effects increase, communication efficiency increase and results in business efficiency improvement.

\section{Research results}

The contribution of this work paper from the standpoint of efficiency of the enterprise (service provider), business place renting such as bazaars and wholesale markets, means that the enterprise should take all necessary elements in communication model with its tenants, in order to increase income. Namely, it is necessary to ascertain that efficient is the enterprise that achieves its economic goals on the market (generated income), and successful communication with tenants gives opportunity for generating new revenues for sellers. A good and successful communication with buyers and consumers offers possibility for existence of sellers on the market and contribute to market efficiency of the enterprise (service provider) within the efficiency model.

It is very important to appreciate specific requirements and wishes that imply adjusting of particular instruments of service marketing mix (Veljković, 2009).

Indeed, the efficiency is one of the key factors that determine business success of a company on the market, its position in comparison to competition and its strategic positions for market survival. We are efficient if we achieve our goals with the knowledge, better thanthe others, by better decision-making, market and market segments selection, great business knowledge, adaptation, flexibility and innovative and ethical business methods. (Prdić, 2018).Nowadays, the efficiency is one of basic factors that determine business success, market position and survival of a modern 
company. Efficiency may be defined as a measure of fulfilled goals. (Prdić et al., 2014). The basic benefit for consumer is value of the product and its effect on the standard. Satisfaction of buyer is one of the most important competitive advantages on a free market of agro industry products. It is necessary to mention that competitive advantage of loyal buyer may be basic condition for taking a part or a greater segment of the market. Serbia should lead active policy of domestic agriculture production incentives, export and import protection of domestic production, according to conditions and rules of worlds market, WTO and EU, within CEFTA agreement. (Kuzman et al., 2013).

Based on theoretical and empirical researches for the cause of this work, it is concluded that the company that rents business place (wholesale market) may generate maximum revenues by using business efficiency model. The same model also works to product sellers within these market institutions and contributes to final consumer satisfaction, by using economic efficiency model and efficiency of communication model.

Figure 1. Business efficiency model

\section{BUSINESS EFFICIENCY MODEL}

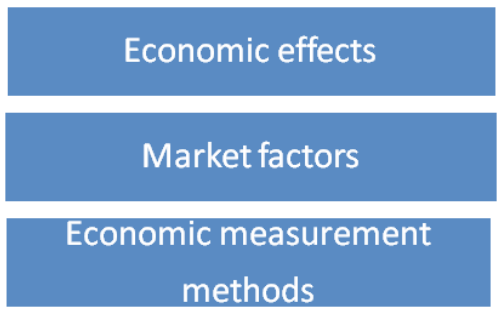

Efficient economic model
Communication effects

Effect of communication

changes

Integration of communication

Measurement of

communication efficiency

\section{INCREASED EFFICIENCY MODEL}

Source: Research results for requirements of this work

After conducting research for the purposes of this paper, based on the theoretical views of scientists in this field, their own experience and the experience of the authors of this paper, surveyed tenants of commercial space at the Kvantaška Market in Novi Sad on the importance of prices and other factors to the success of business, especially the importance of specialised market institutions such as are wholesale markets and marketplaces in countries with a large share of rural agricultural population, which Serbia belongs to, according to the data of the Business Association "Markets of Serbia" in the amount of over $80 \%$ prevalence, it can be concluded, that the future of the domestic agro-industry in trade in agricultural products lies in the development of these market institutions. Hypothesis $\mathrm{H} 1$ was confirmed by empirical research on the sample 
of 500 sellers through a questionnaire when it comes to business success but also their views as (tenants) on the importance of rental prices on performance business. Previous views, specialist literature and the author's experience have contributed to the proposal of a cost-effectiveness model which confirms to $\mathrm{H} 1$ that by taking all steps in the cost-effectiveness model of a business, service providers can increase their revenues. Hypothesis $\mathrm{H} 2$ was confirmed on the basis of customer surveys, vendor attitudes and analysis of the provider's business (periodic balance sheet) as well as the views of experts in the field. Of course, the great experience of the author contributes to these views, when it comes to reaching certain conclusions for the future of these market institutions, but also contributes to both theoretical views and practical applications.

\section{Conclusion}

Based on the conducted research for the purposes of this paper, the conclusion is that companies that trade agro-industrial products or perform certain services in this type of trade should define the business strategy of marketing communication. The basic elements of such a strategy should be contained in the model of realization, economic revenues, as well as in the marketing communication model, in order to achieve the goals of the company on the market. The conducted research also confirmed the hypothesis of research, i.e. it has been proven that the optimized price is the most important instrument for renting space in the opinion of the sellers of goods carried out at the Kvantaška market in Novi Sad, which consequently means increasing the income to the service provider in terms of the number of leased points and increase of total income. It can also be concluded that the acceptable price is the most important factor in the opinion of buyers for deciding on the purchase of products confirmed by examining their attitudes on the same market. The conducted research also proves the hypothesis that a higher degree of integration of marketing communication instruments is a basic requirement for increasing business efficiency, which can be concluded in the model of communication efficiency conducted at the wholesale market by direct examination of attitudes. This conclusion further confirms the hypothesis that the degree of integration of communication leads to greater efficiency of business, especially when, is known, but also proven, that direct communication is the most effective instrument that allows the increased sales. It can be concluded that the elements of business efficiency were achieved by applying these models, as well as the confirmed hypothesis of the research. Of course, under the increase in revenues, we mean maximum space for rent, at acceptable prices for vendors (tenants), which can therefore increase their sales of products, and customers and consumers have a unique place of purchase, quality products at affordable prices and at specialized trading venues. So, we are efficient if we increase our revenues by achieving our business goals, the effects of which are in the interests of economic interest and direct and efficient communication.

The conducted research enabled the achievement of the basic goal of the paper, and the paper presents the importance of the strategic approach to prices to the marketing communication, and the assumptions in the hypothesis of research in the form of 
the importance of integrated marketing communication in the function of increasing revenues from services, increased trade, and customer satisfaction are determined. Bearing in mind that the main goal of the paper is concentrating on the research, roles, significance and effects of wholesale markets in the system of trade in agro-industrial products in order to increase revenues on the one hand, as well as the results of empirical research on the market position of sellers in these market institutions, on the other hand, anticipate and identify all obstacles, and eliminate dilemmas that are related to improving the market position of these companies in order to satisfy the interests of consumers as end users and be applied in practice.

\section{Conflict of interests}

The authors declare no conflict of interest.

\section{References}

1. Aker, D. A., Kumar, V. Dej, S. Dž. (2008), Marketinško istraživanje, Ekonomski fakultet, Beograd [in English: Aker, D. A., Kumar, V. Dej, S. Dz. (2008), Marketing Research, Faculty of Economics, Belgrade]

2. Vračar, D. (2007), Strategije tržišnog komuniciranja, CID, Ekonomski fakultet, Beograd [in English: Vračar, D. (2007), Market Communication Strategies, CID, Faculty of Economics, Belgrade]

3. Duvnjak, S. (2013), Pravci razvoja pijačne delatnosti u Srbiji, Poslovno udruženje „Pijace Srbije“, Beograd [in English: Duvnjak, S. (2013), Directions for the Marketplace Industry in Serbia, Business Association "Markets of Serbia”, Belgrade]

4. Kliestik, T., Misankova, M., Valaskova, K., \& Svabova, L. (2018). Bankruptcy prevention: new effort to reflect on legal and social changes. Science and Engineering Ethics, 24(2), 791-803.

5. Kotler, F. i Li, N. (2008), Marketing u javnom sektoru, Data status, Beograd [in English: Kotler, F. and Li, N. (2008), Public Sector Marketing, Data Status, Belgrade]

6. Kotler, P. (2003), Marketing menadžment, Prentice Hall [in English: Kotler, P. (2003), Marketing Management, Prentice Hall]

7. Kotler, F., Vong, V., Sonders, Dž. i Armstrong, G. (2007), Principi marketinga, Mate, Beograd [in English: Kotler, F., Wong, V., Sonders, Dz. and Armstrong, G. (2007), Principles of Marketing, Mate, Belgrade]

8. Kovacova, M., \& Kliestik, T. (2017). Logit and Probit application for the prediction of bankruptcy in Slovak companies. Equilibrium. Quarterly Journal of Economics and Economic Policy, 12(4), 775-791.

9. Kuzman, B., Tešić, A., \& Đelić, A. T. (2013). Possible routes of approaching of Serbia (agro industrial complex) to the EU and the WTO. Economics of Agriculture, 60(3), 541-549. 
10. Kuzman, B., Prdić, N., \& Dobraš, Z. (2017). The importance of the wholesale markets for trade in agricultural products. Economics of Agriculture, 64(3), 1177-1190.

11. Kuzman, B., \& Prdić, N. (2018). Strategic significance of wholesale markets in agricultural products sale. Economics of Agriculture, Sustainable agriculture and rural development in terms of the Republic of Serbia strategic goals realization within the Danube region. 87-104. http://repository.iep.bg.ac.rs/65/1/1\%20-\%20 Prdic\%2C\%20Kuzman.pdf

12. Lovreta, S. (2008),,Opravdanost izgradnje veletržnice na mikrolokaciji“"Strategija razvoja trgovine grada Beograda, Ekonomski fakultet, NICEF, Beograd [in English: Lovreta, S. (2008) "Justification for the construction of a wholesale market at a microlocation", Belgrade Trade Development Strategy, Faculty of Economics, NICEF, Belgrade]

13. Milisavljević, M. (2003), Marketing, Savremena administracija, Beograd

14. Ognjanov, G. (2009), Integrisane marketinške komunikacije, Ekonomski fakultet, Centar za izdavačku delatnost, Beograd [in English: Ognjanov, G. (2009), Integrated Marketing Communications, Faculty of Economics, Publishing Center, Belgrade]

15. Paraušić, V., Cvijanović, D., Subić, J. (2007): Afirmacija udruživanja i marketinga u funkciji kreiranja konkurentnosti agrarnog sektora Srbije, monografija, Institut za ekonomiku poljoprivrede, Beograd [in English: Paraušić, V., Cvijanović, D., Subić, J. (2007): Affirmation of Associations and Marketing in Function of Creating Competitiveness of the Agricultural Sector of Serbia, Monograph, Institute for Agricultural Economics, Belgrade]

16. Pickton, D. Broderick, A. (2001), Integrated Marketing Comunication, Pearson Education, England

17. Prdić, N., Kuzman, B., \& Barjaktarović, M. (2014). Practical research results of a successful company's appearance at the fair. Economics of Agriculture, 61(2972016-3637), 903-914.

18. Prdić, N. (2014), Istraživanje stavova potrošača o kupovini na pijacama ,Agroekonomika,43 (63-64) [in English: Prdić, N. (2014), "Exploring consumer attitudes to shopping at markets", Agroekonomika, vol. 43, iss. 63-64]

19. Prdić, N. (2016). Competitive adventage on the basis of the strategy low price. Ekonomika, 62(1), 163-174.

20. Prdić, N. (2018), Sajmovi, komunikacija, prodaja, Prometej, Novi Sad [in English: Prdić, N. (2018), Trade shows, communication, sales, Prometheus, Novi Sad]

21. Stanković, L., Đukić, S., \& Popović, A. (2012). Istraživanje motiva i stavova potrošača o turističkim destinacijama. Marketing, 43(2), 104-113. [in English: Stanković, Lj. Djukic, S. and Popovic, A. (2012), Investigating the Motives and Attitudes of Consumers on Tourist Destinations, Marketing]

22. Smit, P.R. (2002), Marketinške komunikacije, Clio, Beograd [in English: Smit, P.R. (2002), Marketing communications, Clio, Belgrade] 
23. Valaskova, K., Kliestik, T., \& Kovacova, M. (2018). Management of financial risks in Slovak enterprises using regression analysis. Oeconomia Copernicana, 9(1), 105-121.

24. Veljković, S. (2009), Marketing usluga, Ekonomski fakultet, Beograd [in English: Veljković, S. (2009), Marketing Services, Faculty of Economics, Belgrade]

25. Vlahović, B. i Puškarić, A. (2014), Međunarodni promet smrznutog povrća - stanje i tendencije, Agroekonomika, 8(1), 13-22, [in English: Vlahović, B. and Puškarić, A. (2014), "International frozen vegetable turnover - state and tendencies", Agroeconomics]

26. Vlahović, B. (2013), Tržište agroindustrijskih proizvoda,Poljoprivredni fakultet, Novi Sad [in English: Vlahović, B. (2013), Market for Agro-Industrial Products, Faculty of Agriculture, Novi Sad]

27. Zakić, V., Kovačević, V., Ivkov, I., \& Mirović, V. (2014). Importance of public warehouse system for financing agribusiness sector. Economics of Agriculture, 61(297-2016-3641), 929-943. 